\title{
Use of Intravenous Immunoglobulins in Sepsis Therapy-A Clinical View
}

\author{
Dominik Jarczak ${ }^{(D}$, Stefan Kluge and Axel Nierhaus *(i) \\ Department of Intensive Care Medicine, University Medical Center Hamburg-Eppendorf, \\ 20246 Hamburg, Germany; d.jarczak@uke.de (D.J.); s.kluge@uke.de (S.K.) \\ * Correspondence: nierhaus@uke.de
}

Received: 3 July 2020; Accepted: 30 July 2020; Published: 3 August 2020

check for updates

\begin{abstract}
Sepsis is a life-threatening organ dysfunction, defined by a dysregulated host immune response to infection. During sepsis, the finely tuned system of immunity, inflammation and anti-inflammation is disturbed in a variety of ways. Both pro-inflammatory and anti-inflammatory pathways are upregulated, activation of the coagulation cascade and complement and sepsis-induced lymphopenia occur. Due to the manifold interactions in this network, the use of IgM-enriched intravenous immunoglobulins seems to be a promising therapeutic approach. Unfortunately, there is still a lack of evidence-based data to answer the important questions of appropriate patient populations, optimal timing and dosage of intravenous immunoglobulins. With this review, we aim to provide an overview of the role of immunoglobulins, with emphasis on IgM-enriched formulations, in the therapy of adult patients with sepsis and septic shock.
\end{abstract}

Keywords: immune response; immunoglobulins; sepsis; septic shock; IVIg; IgGAM

\section{Introduction}

Sepsis is a life-threatening, dysregulated immune response that occurs, when the body's defensive reactions against infection damage its own tissues and organs [1]. In 2017, an estimated 48.9 million cases of sepsis were recorded worldwide with 11.0 million sepsis-related deaths, representing $19.7 \%$ of all global deaths [2]. Due to continuous progress in the understanding of the underlying pathology and immunological mechanisms, the definition of sepsis as a clinical syndrome is subject to constant development. The current consensus definition ("Sepsis-3") emphasizes for the first time the crucial role of the innate and adaptive immune response in the development of the clinical syndrome. Despite the enormous efforts made during the last three decades of clinical and experimental research, the available therapeutic armamentarium to positively affect the course of the disease remains restricted. Even today, the mortality of septic shock, the most severe subgroup of sepsis, lies in the range of more than $50 \%$ in North America and Europe [3].

\section{The Changing Immune System in Sepsis}

In contrast to an uncomplicated and often localized infection, sepsis leads to a system-wide release of cytokines, mediators and pathogen-related molecules ("cytokine storm") [4]. The starting signal for the activation of numerous signal cascades is given by the recognition of pathogen-derived molecules (pathogen-associated molecular patterns, PAMPs-e.g., endo- and exotoxins, lipids, DNA) or endogenous host-derived danger signals (damage-associated molecular patterns, DAMPs) via specific receptors (toll-like receptors, TLR) on the surface of monocytes and antigen-presenting cells (APCs). This initiates the clinical syndrome of sepsis through expression of genes involved in inflammation, cellular metabolism and adaptive immunity [5]. 
Pro- and anti-inflammatory pathways are upregulated, leading to inflammation and progressive tissue damage, ultimately causing multi-organ dysfunction. Simultaneous immunosuppression by downregulation of activating cell surface molecules, $\mathrm{T}$ cell exhaustion and increased apoptosis of immune cells invariably accounts for "immunoparalysis" during the later stages of the disease, making the affected patients susceptible for nosocomial infections, viral reactivation and opportunistic pathogens (Figure 1) [6,7].

\section{Innate immune system $\longleftrightarrow$ Adaptive immune system}

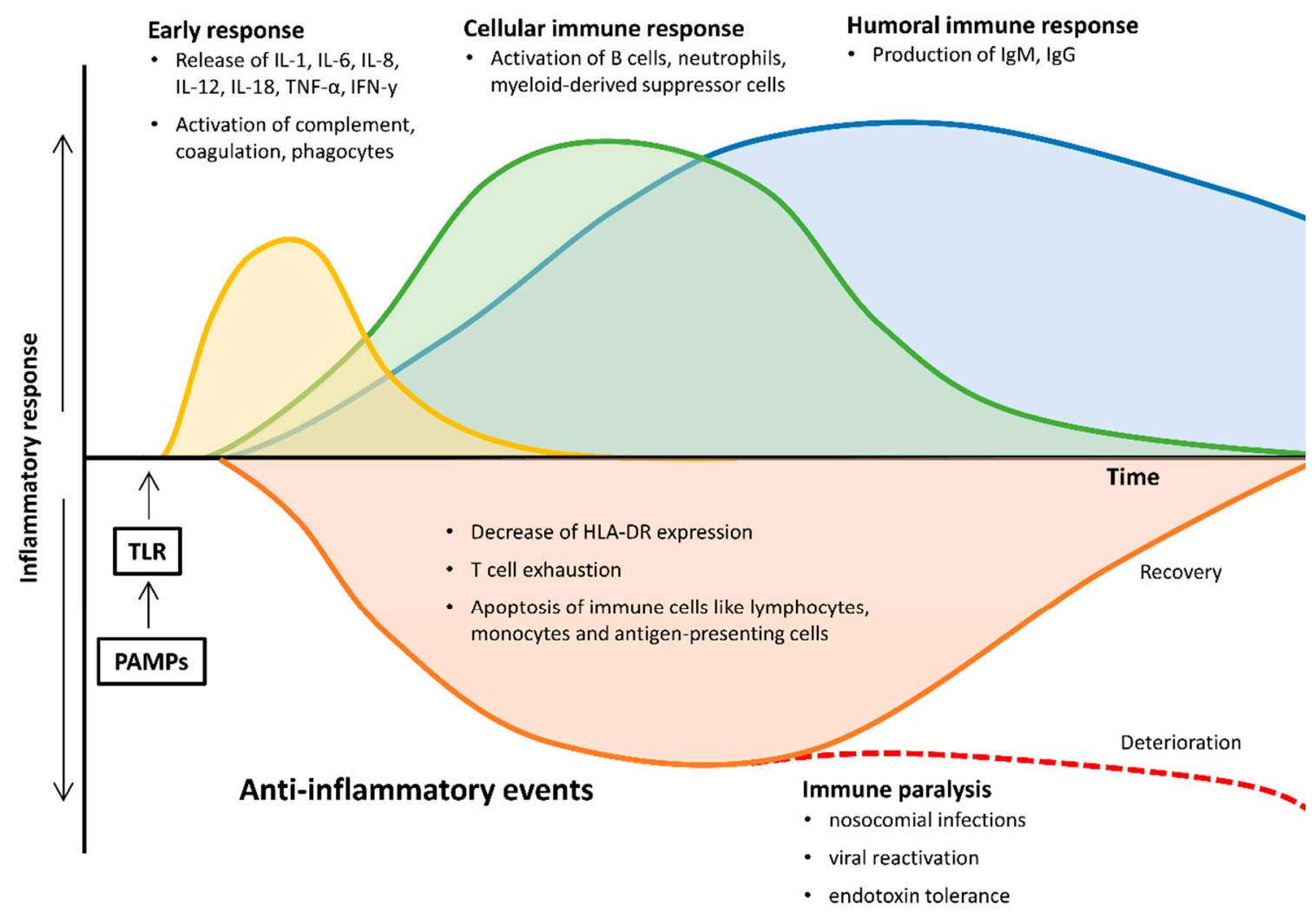

Figure 1. Pro- and anti-inflammatory changes of the immune system during the course of sepsis and septic shock. HLA-DR, human leukocyte antigen-D related; IgM/G, immunoglobulin $\mathrm{M} / \mathrm{G}$; IL, interleukin; IFN- $\gamma$, Interferon gamma; PAMPs, pathogen-associated molecular patterns; TNF- $\alpha$, tumor necrosis factor alpha; TLR, toll-like receptor.

\subsection{Early Pro- and Anti-Inflammatory Responses}

Binding of PAMPs and DAMPs to TLRs on monocytes and APCs causes signal transduction and induces the translocation of nuclear factor kappa-light-chain-enhancer of activated B cells (NF- $\mathrm{kB}$ ) to the nucleus. In consequence, so-called "early activation genes" are expressed, including various pro-inflammatory interleukins (IL), e.g., IL-1, IL-12, IL-18, tumor necrosis factor alpha (TNF- $\alpha$ ) and interferons (IFNs). These changes lead to activation of further cascades of inflammatory cytokines (e.g., IL-6, IL-8, IFN- $\gamma$ ), the coagulation cascade and complement in addition to a downregulation of adaptive immunity components [8]. As a result, increased levels of both pro-inflammatory and anti-inflammatory cytokines can be detected in the early stages of sepsis $[7,9,10]$.

\subsection{Late and Persistent Immunosuppressive Events}

Even though the early systemic inflammatory response is generally considered the hallmark of sepsis, there is also a significant component of immunosuppression that occurs both early and late in the host sepsis response [8]. The role of B-lymphocytes in sepsis exceeds the production and secretion of immunoglobulins, they also modulate the innate immune response, produce cytokines 
and act as APCs [11,12]. In the early course of sepsis, a decrease in lymphocytes, monocytes and antigen-presenting dendritic cells has been observed $[13,14]$. The delicate mechanisms underlying sepsis-induced lymphopenia have not yet been conclusively explained. As a possible explanation, recruitment of lymphocytes from the peripheral circulation into areas of inflammation and infection is discussed, but most data suggest that apoptosis causes sepsis-induced lymphopenia [15-17]. The persistence of lymphopenia and therefore also the lower levels of immunoglobulins over the course of sepsis is closely associated with increased mortality $[17,18]$.

\subsection{Monocytes and Antigen-Presenting Cells}

In addition to sepsis-induced lymphopenia, an increase in apoptosis of monocytes and APCs could be shown, which is accompanied by a significant loss of pro-inflammatory cytokine production [13,14,19-27]. The remaining cells also present with a decreased expression of the human leukocyte antigen DR (HLA-DR) on their surface, resulting in a diminished ability to recognize pathogens and to interact with $\mathrm{T}$ cell receptors via opsonisation. As a consequence, this leads to a lack of Th1- and Th2-response as a component of the adaptive immune response [28]. The inability of monocytes to restore normal expression levels of HLA-DR has been shown to predict poor outcome in sepsis $[29,30]$. Furthermore, it has also been shown that endotoxin tolerance in the early course of sepsis is also associated with further clinical deterioration [31].

\subsection{Neutrophils}

As part of the innate immune system, neutrophils belong to the first line of defence against pathogens. Severe bacterial infections result in emergency granulocyte formation and the release of both mature and immature forms of neutrophils from the bone marrow. When activated via PAMPs and DAMPs in septic patients, these cells show reduced phagocytosis and oxidative burst capacity [32]. High levels of immature granulocytes in sepsis are associated with clinical deterioration, since these have shown increased spontaneous production and liberation of neutrophil extracellular traps (NETs) [33,34]. NETs are diffuse extracellular structures of decondensed chromatin with granular and nuclear proteins $[35,36]$. These structures have the potential to capture a wide range of pathogens, including Gram-positive and Gram-negative bacteria, viruses, yeasts, but also protozoa and parasites that cannot be phagocytized due to their size [37]. It is known that cytokines, chemokines, platelet agonists and antibodies can also trigger their release. The pronounced presence of NETs in tissues or vessels due to insufficient removal or overproduction is linked to hypercoagulation and endothelial injury [34,38,39].

\subsection{Myeloid-Derived Suppressor Cells}

During granulopoiesis as a response to acute infection, immature myeloid cells can shift into the peripheral blood and become functionally active. These myeloid-derived suppressor cells (MDSCs) release various anti-inflammatory cytokines (e.g., IL-10 and transforming growth factor $\beta$, TGF- $\beta$ ), leading to further immunosuppression $[8,40]$. These immunosuppressing properties have been the focus of extensive research in the context of malignant diseases, but the knowledge in relation to sepsis is still scarce [41].

\subsection{B-Lymphocytes}

Although many details are known about the function of B-lymphocytes in the context of sepsis, their clinical relevance cannot yet be conclusively determined. For an effective host protection, B cell function and antibody expression are decisive factors. The production of antibodies is one of the crucial functions of B cells after differentiation into high-affinity antibody-secreting plasma cells [42]. Within the framework of the adaptive immune response, interaction with dendritic cells, macrophages, $\mathrm{T}$ - and other B- cells leads to clonal expansion and finally to the production of specific antibodies. However, in the early phase of sepsis, B cells can also be activated by pathogens themselves via 
pathogen recognition receptors (PRRs), which leads to an initial immune response by innate like B cells $[11,43,44]$.

Just at the beginning of sepsis, the number of B-lymphocytes in the peripheral blood is often reduced $[45,46]$. In addition to increased apoptosis, increased migration from the circulation into the tissue or reduced production of these B cells in favour of the production of monocytes and neutrophils as part of an emergency haematopoiesis is possible as a cause. A recent study by Dong et al. showed that in septic shock, a severe functional impairment of B cells is present in non-survivors, resulting in both lower serum immunoglobulin M (IgM) levels and in lower IgM production upon B cell stimulation. Examining five subsets of peripheral blood B cells (immature/transitional B cells, naive B cells, tissue-like memory B cells, resting memory B cells, and activated memory B cells), the authors demonstrated a distinct redistribution of these subsets in septic shock patients when compared to healthy controls [47].

A meta-analysis could show that the number of circulating B cells is significantly higher in sepsis survivors than in sepsis non-survivors, especially within the first $24 \mathrm{~h}$ after the onset of sepsis [48]. The mechanism presumably responsible for this protective effect seems to be the release of natural antibody IgM, which plays a key role in the fight against gram-negative infections in particular [11]. Furthermore, it could be shown that IgM plasma levels in survivors of sepsis or septic shock were higher in the first $24 \mathrm{~h}$ than in non-survivors, which supports the hypothesis of a protective function of $\mathrm{B}$ cells through the production of IgM [48]. Interestingly, a similar relationship was also shown in non-septic critically ill patients [49]. However, current data are not yet sufficient to use the measurement of B cells or IgM levels in early sepsis as a prognostic factor for outcome.

\subsection{Immunoglobulins}

Immunoglobulins are glycoproteins secreted by differentiated B cells, so called plasma cells. Each immunoglobulin molecule monomer consists of identical light and heavy chain pairs, held together by disulphide bonds and electrostatic forces. Based on the heavy chain, there are five isotypes of immunoglobulins, IgA, IgD, IgE, IgG and $\operatorname{IgM}$, respectively [50]. The variable regions of immunoglobulins enable non-covalent cross-linking to bacterial and other antigens, whereby the constant region transduces signals in response to antigen-binding. The most important classes within the human humoral immune system are IgA, IgG and IgM. IgA has two subclasses (IgA1, IgA2) and the main function is mucosal immunity. IgG has four subclasses (IgG1-IgG4) and the key functions besides secondary antibody responses are opsonisation and complement activation. The main functions of IgM are complement activation and primary antibody responses. Two types (kappa and lambda) of light chains are also present in the circulation independent of whole immunoglobulin molecules, referred to as free light chains (FLC), which can be detected at abnormal high levels in adult patients with sepsis [51].

\section{Considerations for the Therapeutic Use of Immunoglobulins}

The concept that acquired immunosuppression is a significant event in sepsis and septic shock leads to the hypothesis that stimulation of the immune response and/or substitution of individual immune system components could be a promising therapeutic approach. Within the intricate web of interacting and regulating factors of the immune system and the inflammatory response, polyvalent intravenous immunoglobulins (IVIg) might be a tool for modulating both pro- and anti-inflammatory processes (Figure 2).

The clinical rationale for IVIg therapy in sepsis can be categorized as follows: the role of immunoglobulins in (i) recognition and clearance of pathogens and toxins, (ii) scavenging and inhibition of up- and downstream mediator gene transcription, and (iii) anti-apoptotic effects on immune cells. 


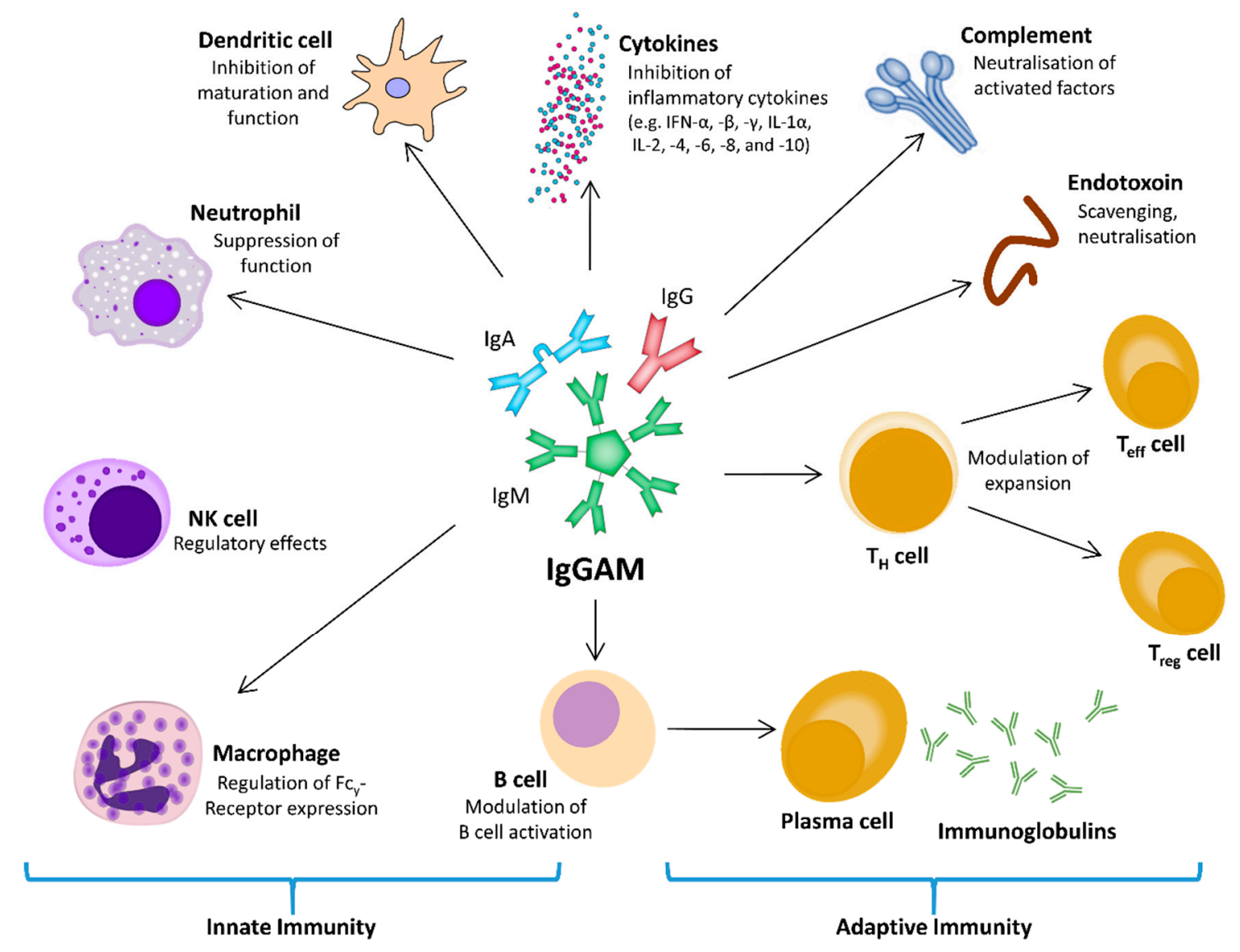

Figure 2. The central role of intravenous immunoglobulins IgGAM on the innate and adaptive immune response, using different regulatory pathways to interact with the cellular and humoral components. IFN, interferon; Ig, immunoglobulin; IgGAM, immunoglobulin G/A/M; IL, interleukin; NK cell, natural killer cell; $\mathrm{T}_{\text {eff }}$ cell, effector $\mathrm{T}$ cell; $\mathrm{T}_{\mathrm{H}}$ cell, helper $\mathrm{T}$ cell; $\mathrm{T}_{\text {reg }}$ cell, regulatory $\mathrm{T}$ cell.

Recognition of PAMPs is based on naturally occurring antibodies, which can also act as innate immune receptors. IgG and the complement proteins are the most important opsonins for bacterial clearance. The activation of the classical pathway of the complement system is activated by the interaction of $\mathrm{C} 1$ complex with immunoglobulins, acute phase proteins and non-specific activators [52]. Human neutrophils express multiple Fc $\gamma$-type cell surface receptors, that are capable of binding IgG, resulting in neutrophil activation via tyrosine kinase pathways and thereby upregulating the expression of phagocytic receptors, that are able to identify and phagocytose pathogens opsonized with IgG and complement proteins $[53,54]$. Due to IgG deficit, the activation of neutrophils as well as phagocytosis signals may be affected in septic patients, so this population seems to be an optimal cohort for IVIg therapy.

Monocytes and T cells also become activated by superantigen exotoxins released by staphylococci and streptococci. IgG molecules contained in IVIg preparations can inhibit or neutralise these superantigens, thereby preventing superantigen-mediated $\mathrm{T}$ cell and monocyte activation [55-57].

A key mechanism for regulating host response in inflammatory situations like sepsis or septic shock (as well as other inflammatory diseases) is NF-kB-mediated up-regulation of IL-1 and the IL-1 receptors system [58]. It has been shown, that these components decrease, if IVIg is supplemented in case of hypogammaglobulinaemia or sepsis, as well as IL-1 mediated activity of mononuclear cells in peripheral blood reduces and IL-1 receptor antagonist (IL-1ra) becomes induced [58,59].

In addition to neutralising antibodies in IVIg preparations, naturally occurring auto-antibodies, antiidiotype antibodies and immune proteins in IVIg preparations may also contribute to its immunomodulatory properties [60]. In healthy individuals, autoantibodies neutralising cytokines 
such as IFN- $\alpha,-\beta$ and $-\gamma$, IL- $1 \alpha,-2,-4,-6,-8,-10$, TNF- $\alpha$ and $-\beta$, and soluble TNF receptors have been regularly detected. Therefore, polyclonal IVIg formulations are likely to contain these antibodies, which contribute to cytokine modulation as another important component of anti-inflammatory IVIg activity [61-63].

Alas, despite the numerous theoretical advantages clinical studies have shown that the administration of preparations containing only IgG did not lead to a reduction in mortality in patients with sepsis [64-66]. However, systematic reviews and meta-analyses suggest that the use of preparations with enriched IgA and IgM (IgGAM) is associated with a higher survival rate [67-71]. A recent meta-analysis, including 19 trials with more than 1500 patients showed a significant reduction in mortality when using IgM- and IgA-enriched immunoglobulins compared to human albumin solution or no special treatment as a control intervention [67]. In addition, a post-hoc analysis of the CIGMA trial demonstrated a significant relative reduction in all-cause mortality of $54-68 \%$ using IgM- and IgA enriched immunoglobulins in patients with severe pneumonia and had high C-reactive protein (CRP), low IgM and high CRP/low IgM ratios at baseline compared to placebo [72]. Conversely, patients with normal IgM levels showed a tendency towards higher mortality in the treatment group $(10 / 25 \mathrm{vs} .5 / 24, p=0.2165)$, which might suggest that precise identification of the target population is essential. Further, a recent clinical trial, in which patients were treated with either IgGAM or placebo $(\mathrm{NaCl})$, demonstrated a significant decrease in IL-6 and IL-10 levels after $72 \mathrm{~h}$ only in the IgGAM group [73]. A positive effect of IgM administration on microvascular perfusion parameters could be demonstrated in humans, confirming previous studies in an animal model of endotoxemia $[73,74]$. IgM has also been shown to have a positive effect on the integrity of the blood-brain barrier and on septic encephalopathy in rats [75,76].

The decrease of systemic endotoxin levels associated with IgGAM has been shown in animal models. Human studies have focused on neonates and preterm infants, or on neutropenic patients [77-79]. Recently, a small controlled study in adult patients with sepsis and septic shock and elevated endotoxin levels demonstrated that IgGAM significantly attenuated LPS levels and had a beneficial effect on sepsis-related coagulopathy in terms of platelet count and fibrinogen concentrations [80].

The precise mechanisms by which IgGAM brings about these effects in patients with sepsis or septic shock are not conclusively clarified until now. In addition to the opsonisation of pathogens and the neutralization of bacterial endotoxins and exotoxins, IgGAM modulates the immune response by attenuating an excessive inflammatory response [80-83]. The reduced production of IL-2 when IgGAM is used is considered to be one of the proven mechanisms of action [84]. IL-2 (also T cell growth factor, TCGF) is mainly produced by activated T cells and is released after MHC-II-mediated recognition of an antigen. It is mainly autocrine and serves two opposite functions: On the one hand, IL-2 enhances the proliferative response of effector $\mathrm{T}$ cells ( $\mathrm{T}_{\text {eff }}$ cells) and natural killer cells (NK cells), on the other hand IL-2 simultaneously controls immune homeostasis by influencing proliferation, differentiation and function of regulatory $\mathrm{T}$ cells ( $\mathrm{T}_{\text {reg }}$ cells) [85].

Overall, this leads both in vitro and in lectin-stimulated peripheral blood mononuclear cells to a significant inhibition of the alloproliferative response of human T-lymphocytes $[84,86]$. Immunoglobulin-induced downregulation of IL-2 also causes a lack of activation of B-lymphocytes and decreases the production of pro-inflammatory TNF- $\alpha$ as well as the cytokines of the type 2 T-helper cell response, IL-4 and IL-5 [87].

\section{Immunoglobulins in Clinical Use}

Up to now, the use of intravenous Ig as supportive therapy in sepsis is controversial and not entirely without risk. In some patients, serious adverse reactions consist of the development of a hyperviscosity syndrome with thromboembolic events. Further, acute renal failure has been observed, which was presumably associated with stabilizers contained in the IVIg preparations. IVIg-associated renal failure is most common in patients with pre-existing conditions such as renal impairment, diabetes mellitus, advanced age, volume depletion or concomitant use of other substances known to 
cause renal toxicity [88]. However, most of these potential complications can be prevented by taking appropriate countermeasures. For example, slow infusion rates and adequate hydration may help to avoid renal failure as well as thromboembolic events [89].

Nevertheless, due to their pleiotropic effects and the potential modulation of both pro- and anti-inflammatory processes, polyvalent intravenous immunoglobulins offer a promising strategy within the context of inflammation and immunity. Experimental studies have shown that polyvalent immunoglobulins can improve phagocytosis of pathogens via opsonisation, neutralize exo- and endotoxins and interact with complement factors, thereby preventing nonspecific activation [80,82-84]. Nevertheless, the Surviving Sepsis Campaign (SSC) guidelines suggested against IVIg use in sepsis therapy 2016 due to lack of sufficient evidence of efficacy for preparations containing only IgG [90]. Prepared from a pool of donors, IVIg are widely used in the treatment of haematological, immunological, and neurological diseases. Classic IVIg-preparations contain more than 90\% IgG. Since human plasma contains all three immunoglobulin classes, IgGAM preparations are considered physiological [91].

Pentaglobin is currently available as a preparation in which the proportion of $\operatorname{IgM}$ and IgA is enriched to $12 \%$ each, with an IgG proportion of $76 \%$. Pentaglobin also contains toxin-binding and neutralising antibodies against numerous Gram-positive and Gram-negative bacteria and influences the effect of further pro-inflammatory (IFN- $\gamma$, IL-6) and anti-inflammatory (IL-10) cytokines during the lymphocyte response $[84,92,93]$. Another preparation with an even higher proportion of $\operatorname{IgM}(23 \%)$ and IgA (21\%) is in clinical development under the working name Trimodulin [72].

Most of the evidence currently available on the use of IgGAM in sepsis or septic shock is based primarily on the use of Pentaglobin in clinical trials. Unfortunately, these data suffer from the fact that, in addition to a large number of different protocols (various dosages, heterogeneous patients), the laboratory parameters analysed are also inconsistent [94].

The Questions of "Who?", "When?" and "How Much?"

Understanding which patients can generally benefit most from therapy with IgGAM is of high clinical relevance. Previous studies investigating immunomodulatory approaches in the treatment of sepsis often lacked a precise characterization of suitable patients [95-99]. According to the current state of knowledge, the identification of a suitable target population for IgGAM therapy is important. In particular, the idea of "one size fits all" therapy must be critically examined under the current concept of "personalised medicine" and also the lack of cost-effectiveness data [100-104].

In 2005, a meta-analysis investigated 9 trials including 435 patients, and showed an increase of direct ICU costs for the treatment of adult patients with severe sepsis and septic shock with IgGAM by $€ 2037$, but this was offset by costs per life saved of $€ 10,565$ [105]. This analysis demonstrated also a significantly reduced mortality risk but showed no effect on ICU length of stay. As many other analyses in this context, this was based on small trials of variable quality.

As a complex syndrome, sepsis is characterized by a variety of pathogen- and host-specific factors that show a very dynamic behaviour over time [1]. Especially patients with the appearance of an excessive immune reaction, but also those with the appearance of an immune paralysis (hypoinflammation), seem to be qualified for the use of IgGAM. As a consequence of sepsis-related hyperinflammation, all organs can be affected and numerous biomarkers can be influenced, including CRP, procalcitonin (PCT) and IL-6 [106]. To date there is no clear predictor for the use of IgGAM. The shock index and the qSOFA score (quick sepsis-related organ failure) are also readily available and cost-effective tools for the initial assessment of high-risk patients [107,108].

The measurement of circulating immunoglobulins as biomarkers in sepsis has increasingly become the focus of research within the last ten years. Different approaches are pursued with regard to the development of immune scores as a tool for predicting outcome. A meta-analysis could show that the prevalence of IgG hypogammaglobulinaemia in heterogeneous sepsis cohorts at the time of sepsis diagnosis was as high as 70\%, however, a single subnormal measurement of IgG on the day of sepsis diagnosis could not help to identify patients with a higher risk of death [109]. In another study, 
the combination of several Ig parameters was found to be significantly associated with an unfavourable outcome when levels of IgA, IgG and IgM were below specified cut offs [110]. This finding is consistent with the evidence from a retrospective analysis of 129 patients with septic shock treated with IgGAM, where a survival benefit was associated with the start of treatment within the first $23 \mathrm{~h}$ [111].

In addition to the excessive, pro-inflammatory immune response, the syndrome of acquired septic immune paralysis has become the focus of attention, as it seems to be predominantly associated with morbidity and mortality [112]. Although the clinical appearance of hypoinflammation is not as detailed and comprehensive as the phenotype of hyperinflammation, the increased risk of secondary infection in these patients is well known [112]. Patients often develop a chronic critical illness after initial survival of septic shock and cannot leave the intensive care unit.

Chronic immune paralysis can lead to a renewed increase in the mortality rate after about 30 days; patients often suffer from deleterious nosocomial infections: in addition to the occurrence of multi-resistant bacteria (MDR), viral infections (de novo or reactivations) or infections with fungi are also observed, the successful treatment of which remains one of the major challenges of modern intensive care medicine [113-117]. Possibly, the detection of a low HLA-DR expression on monocytes could serve as an indication of (continued) immune dysfunction and thus indicate increased mortality [118-120].

In addition to the identification and selection of suitable patient groups for therapy with IgGAM ("Who?"), the questions of "When?" and "How much?" remain open. There are no clear answers for either aspect. In general, it could be shown that an early start of IgGAM therapy (i.e., $36 \mathrm{~h}$ vs. $66 \mathrm{~h}$, respectively) in the presence of an infection leads to a higher probability of survival, which makes the time factor a key influencing variable [121,122].

There is also a lack of evidence on the question of optimal dosage, which is the basis of current studies. In addition to the pros and cons of an initial bolus application, the type of administration (continuous vs. intermittent), the quantity (determined by serum measurements of Ig or without adaptation), but also that of the target value to be achieved ("normal" or "supranormal") are not sufficiently clarified.

\section{A Novel Situation in COVID-19}

In 2019 the "severe acute respiratory Syndrome coronavirus-2" (SARS-CoV-2) caused a pandemic with an unprecedented global crisis, affecting healthcare and research systems, but also infrastructure sectors, including education, politics and economy.

According to current knowledge, there is a link between severity of coronavirus disease 2019 (COVID-19), viral production and the severe dysregulation of the inflammatory immune reaction ("cytokine storm"). However, up to date it is still unclear which molecular mechanisms trigger the onset of the immune dysbalance and why it can rapidly progress to multiorgan dysfunction or ARDS with a fatal outcome in a considerable subset of patients $[123,124]$.

Clinical observation of fatal courses of COVID-19 often includes severe acute respiratory distress syndrome (ARDS), which is caused by alveolar injury, and multiple organ failure-both of which are associated with hyperproduction of cytokines [123-125]. Both mild and severe/fatal cases display changes in cytokine production, particularly IL-1 $\beta$, IL-1ra, IL-6, IL-10, TNF, GM-CSF, IL-17, and pathological shifts of circulating leukocyte subsets [126,127].

As a consequence, this leads to the disturbed development of protective immunity against the infection. The most severe complications of COVID-19 include sepsis-like inflammation, pulmonary or cardiovascular complications, and coagulopathy [128-130].

As discussed above, the innate immune system of the host is activated in response to the virus to limit infection. Subsequently, the adaptive immune system develops specific immunoglobulins and activates $\mathrm{T}$ cells in direct response to the virus.

However, if this inflammation is unmodulated or excessive, there is a risk of chronic hyperinflammation resulting in functional inhibition of the adaptive immune system. In addition to virus-induced lymphopenia, this can result in progressive tissue and organ damage and the failure of 
the adaptive immune system to develop functional immunoglobulins, thereby clearing the virus [131]. Therefore, the use of IgGAM in patients showing signs of both hyper- and hypoinflammation could be an effective therapeutic strategy.

\section{Conclusions}

To this day, the cornerstones of sepsis and septic shock therapy still consist of timely focus control, the administration of anti-infective drugs and haemodynamic stabilisation through early and sufficient administration of fluid and vasopressors. The clinical understanding of sepsis is evolving towards an immunological perspective and remarkable progress has been made in recent decades. Shedding light on the complex pro- and anti-inflammatory pathways and the disorders of the complementary and coagulation systems, thereby demonstrating the complexity and heterogeneity of the syndrome, has yet not led to transfer this knowledge into evidence-based approaches to treat sepsis and develop effective therapies. Despite progress in the (further) development of innovative therapeutic approaches, such as methods for extracorporeal blood purification, the use of novel anti-infective substances or targeted immune modulation, there are still no therapeutic measures backed up by sufficient evidence that lead to a convincingly reduced mortality in the therapy of sepsis [132].

Therapy with IVIg is a treatment option that is associated with relatively high (but internationally disparate) costs and variable availability of treatment. A targeted selection process of potentially profiting patients on evidence-based criteria in terms of personalized medicine is preferable to an indiscriminate approach. Unfortunately, a reliable and validated assessment of the cost-effectiveness in relation to the total costs of therapy based on available data currently remains difficult to obtain.

Since the approach of using purely anti-inflammatory therapies has been disappointing, the investigation of strategies aiming at balancing the immune system appears to be more appropriate [133]. Given their multiple effects on inflammatory and immune mechanisms, the use of polyclonal intravenous immunoglobulins seems to be a promising approach to both modulate proand anti-inflammatory pathways. However, further clinical studies and research are clearly needed to substantiate the rationale for the use of immunoglobulins presented here, and to target the interventions to the right patient subset, at the right time, at the appropriate dose and for an optimal duration.

Summary:

- The use of IVIg in sepsis and septic shock appears to be safe.

- The use of IgGAM shows beneficial effects on sepsis-related inflammation and coagulopathy.

- For adjunctive sepsis therapy with IVIg, IgM-enriched formulations may be advantageous for specific patients.

- Further clinical data are urgently needed to be able to make definitive statements on the cost-benefit ratio.

Author Contributions: A.N., S.K., D.J.: Conceptualization. D.J., A.N.: Writing—original draft. S.K.: Supervision, revision. All authors have read and agreed to the published version of the manuscript.

Funding: This research received no external funding.

Conflicts of Interest: Dominik Jarczak has received lecture honoraria and travel reimbursement from ADVITOS and CytoSorbents Europe $\mathrm{GmbH}$, Stefan Kluge received lecture honoraria from Arjo-Huntleigh, Astellas, Astra, Basilea, Bard, Baxter, Biotest, CSL Behring, CytoSorbents, Fresenius, Gilead, MSD, Orion, Pfizer, Philips, Sedana, Sorin, Xenios and Zoll. He received consultant honorarium from AMOMED, Astellas, Baxter, Bayer, Fresenius, Gilead, MSD, Pfizer and Xenios. Axel Nierhaus has received lecture honoraria and travel reimbursement from ThermoFisher Scientific GmbH, CytoSorbents Europe GmbH, and Biotest AG, Germany, over the past five years. 


\section{Abbreviations}

$\begin{array}{ll}\text { APC } & \text { antigen-presenting cell } \\ \text { CRP } & \text { C-reactive protein } \\ \text { DAMP } & \text { damage associated molecular pattern } \\ \text { DNA } & \text { desoxyribonucleic acid } \\ \text { HLA-DR } & \text { human leukocyte antigen-D related } \\ \text { ICU } & \text { intensive care unit } \\ \text { IFN } & \text { interferon } \\ \text { IL } & \text { interleukin } \\ \text { IL-1ra } & \text { IL-1 receptor antagonist } \\ \text { Ig } & \text { immunoglobulin(s) } \\ \text { IVIg } & \text { intravenous immunoglobulin } \\ \text { IgGAM } & \text { immunoglobulin G/A/M } \\ \text { MDR } & \text { multi drug resistant } \\ \text { MDSC } & \text { myeloid-derived suppressor cell } \\ \text { MHC } & \text { major histocompatibility } \\ \text { NET } & \text { neutrophil extracellular trap } \\ \text { NF- } k B & \text { nuclear factor kappa-light-chain-enhancer of activated B cells } \\ \text { NK cell } & \text { natural killer cell } \\ \text { PAMP } & \text { pathogen-associated molecular pattern } \\ \text { PCT } & \text { procalcitonin } \\ \text { PRR } & \text { pathogen recognition receptor } \\ \text { qSOFA } & \text { quick sepsis-related organ failure } \\ \text { TCGF } & \text { T cell growth factor } \\ \text { Teff cell } & \text { effector T cell } \\ \text { TGF- } \beta & \text { transforming growth factor- } \beta \\ \text { TH cell } & \text { helper T cell } \\ \text { TLR } & \text { toll-like receptor } \\ \text { TNF- } \alpha & \text { tumor necrosis factor alpha } \\ \text { Treg cell } & \text { regulatory T cell } \\ & \end{array}$

\section{References}

1. Singer, M.; Deutschman, C.S.; Seymour, C.W.; Shankar-Hari, M.; Annane, D.; Bauer, M.; Bellomo, R.; Bernard, G.R.; Chiche, J.D.; Coopersmith, C.M.; et al. The Third International Consensus Definitions for Sepsis and Septic Shock (Sepsis-3). JAMA 2016, 315, 801-810. [CrossRef] [PubMed]

2. Rudd, K.E.; Johnson, S.C.; Agesa, K.M.; Shackelford, K.A.; Tsoi, D.; Kievlan, D.R.; Colombara, D.V.; Ikuta, K.S.; Kissoon, N.; Finfer, S.; et al. Global, regional, and national sepsis incidence and mortality, 19902-017: Analysis for the Global Burden of Disease Study. Lancet 2020, 395, 200-211. [CrossRef]

3. Vincent, J.L.; Jones, G.; David, S.; Olariu, E.; Cadwell, K.K. Frequency and mortality of septic shock in Europe and North America: A systematic review and meta-analysis. Crit. Care 2019, 23, 196. [CrossRef]

4. Chousterman, B.G.; Swirski, F.K.; Weber, G.F. Cytokine storm and sepsis disease pathogenesis. Semin. Immunopathol. 2017, 39, 517-528. [CrossRef]

5. Rubio, I.; Osuchowski, M.F.; Shankar-Hari, M.; Skirecki, T.; Winkler, M.S.; Lachmann, G.; La Rosee, P.; Monneret, G.; Venet, F.; Bauer, M.; et al. Current gaps in sepsis immunology: New opportunities for translational research. Lancet Infect. Dis. 2019, 19, e422-e436. [CrossRef]

6. Tang, B.M.; Huang, S.J.; McLean, A.S. Genome-wide transcription profiling of human sepsis: A systematic review. Crit. Care 2010, 14, R237. [CrossRef] [PubMed]

7. Tamayo, E.; Fernandez, A.; Almansa, R.; Carrasco, E.; Heredia, M.; Lajo, C.; Goncalves, L.; Gomez-Herreras, J.I.; de Lejarazu, R.O.; Bermejo-Martin, J.F. Pro- and anti-inflammatory responses are regulated simultaneously from the first moments of septic shock. Eur. Cytokine Netw. 2011, 22, 82-87. [CrossRef]

8. Hotchkiss, R.S.; Moldawer, L.L.; Opal, S.M.; Reinhart, K.; Turnbull, I.R.; Vincent, J.L. Sepsis and septic shock. Nat. Rev. Dis. Prim. 2016, 2, 16045. [CrossRef] 
9. Andaluz-Ojeda, D.; Bobillo, F.; Iglesias, V.; Almansa, R.; Rico, L.; Gandia, F.; Resino, S.; Tamayo, E.; de Lejarazu, R.O.; Bermejo-Martin, J.F. A combined score of pro- and anti-inflammatory interleukins improves mortality prediction in severe sepsis. Cytokine 2012, 57, 332-336. [CrossRef]

10. Chaudhry, H.; Zhou, J.; Zhong, Y.; Ali, M.M.; McGuire, F.; Nagarkatti, P.S.; Nagarkatti, M. Role of cytokines as a double-edged sword in sepsis. In Vivo 2013, 27, 669-684.

11. Rauch, P.J.; Chudnovskiy, A.; Robbins, C.S.; Weber, G.F.; Etzrodt, M.; Hilgendorf, I.; Tiglao, E.; Figueiredo, J.L.; Iwamoto, Y.; Theurl, I.; et al. Innate response activator B cells protect against microbial sepsis. Science 2012, 335, 597-601. [CrossRef] [PubMed]

12. Kelly-Scumpia, K.M.; Scumpia, P.O.; Weinstein, J.S.; Delano, M.J.; Cuenca, A.G.; Nacionales, D.C.; Wynn, J.L.; Lee, P.Y.; Kumagai, Y.; Efron, P.A.; et al. B cells enhance early innate immune responses during bacterial sepsis. J. Exp. Med. 2011, 208, 1673-1682. [CrossRef] [PubMed]

13. Bhardwaj, N.; Mathur, P.; Kumar, S.; Gupta, A.; Gupta, D.; John, N.V.; Varghese, P.; Misra, M.C. Depressed Monocytic Activity may be a Predictor for Sepsis. J. Lab. Physicians 2015, 7, 26-31. [CrossRef]

14. Fan, X.; Liu, Z.; Jin, H.; Yan, J.; Liang, H.P. Alterations of dendritic cells in sepsis: Featured role in immunoparalysis. BioMed Res. Int. 2015, 2015, 903720. [CrossRef] [PubMed]

15. Hotchkiss, R.S.; Swanson, P.E.; Freeman, B.D.; Tinsley, K.W.; Cobb, J.P.; Matuschak, G.M.; Buchman, T.G.; Karl, I.E. Apoptotic cell death in patients with sepsis, shock, and multiple organ dysfunction. Crit. Care Med. 1999, 27, 1230-1251. [CrossRef]

16. Hotchkiss, R.S.; Tinsley, K.W.; Swanson, P.E.; Chang, K.C.; Cobb, J.P.; Buchman, T.G.; Korsmeyer, S.J.; Karl, I.E. Prevention of lymphocyte cell death in sepsis improves survival in mice. Proc. Natl. Acad. Sci. USA 1999, 96, 14541-14546. [CrossRef]

17. Drewry, A.M.; Samra, N.; Skrupky, L.P.; Fuller, B.M.; Compton, S.M.; Hotchkiss, R.S. Persistent lymphopenia after diagnosis of sepsis predicts mortality. Shock 2014, 42, 383-391. [CrossRef]

18. Venet, F.; Rimmele, T.; Monneret, G. Management of Sepsis-Induced Immunosuppression. Crit. Care Clin. 2018, 34, 97-106. [CrossRef]

19. Venet, F.; Davin, F.; Guignant, C.; Larue, A.; Cazalis, M.A.; Darbon, R.; Allombert, C.; Mougin, B.; Malcus, C.; Poitevin-Later, F.; et al. Early assessment of leukocyte alterations at diagnosis of septic shock. Shock 2010, 34, 358-363. [CrossRef]

20. Cazalis, M.A.; Friggeri, A.; Cave, L.; Demaret, J.; Barbalat, V.; Cerrato, E.; Lepape, A.; Pachot, A.; Monneret, G.; Venet, F. Decreased HLA-DR antigen-associated invariant chain (CD74) mRNA expression predicts mortality after septic shock. Crit. Care 2013, 17, R287. [CrossRef]

21. Kjaergaard, A.G.; Nielsen, J.S.; Tonnesen, E.; Krog, J. Expression of NK cell and monocyte receptors in critically ill patients-potential biomarkers of sepsis. Scand. J. Immunol. 2015, 81, 249-258. [CrossRef] [PubMed]

22. Shalova, I.N.; Lim, J.Y.; Chittezhath, M.; Zinkernagel, A.S.; Beasley, F.; Hernandez-Jimenez, E.; Toledano, V.; Cubillos-Zapata, C.; Rapisarda, A.; Chen, J.; et al. Human monocytes undergo functional re-programming during sepsis mediated by hypoxia-inducible factor-1alpha. Immunity 2015, 42, 484-498. [CrossRef] [PubMed]

23. Hotchkiss, R.S.; Tinsley, K.W.; Swanson, P.E.; Schmieg, R.E., Jr.; Hui, J.J.; Chang, K.C.; Osborne, D.F.; Freeman, B.D.; Cobb, J.P.; Buchman, T.G.; et al. Sepsis-induced apoptosis causes progressive profound depletion of B and CD4+ T lymphocytes in humans. J. Immunol. 2001, 166, 6952-6963. [CrossRef] [PubMed]

24. Delano, M.J.; Scumpia, P.O.; Weinstein, J.S.; Coco, D.; Nagaraj, S.; Kelly-Scumpia, K.M.; O’Malley, K.A.; Wynn, J.L.; Antonenko, S.; Al-Quran, S.Z.; et al. MyD88-dependent expansion of an immature GR-1(+)CD11b(+) population induces T cell suppression and Th2 polarization in sepsis. J. Exp. Med. 2007, 204, 1463-1474. [CrossRef] [PubMed]

25. Taneja, R.; Sharma, A.P.; Hallett, M.B.; Findlay, G.P.; Morris, M.R. Immature circulating neutrophils in sepsis have impaired phagocytosis and calcium signaling. Shock 2008, 30, 618-622. [CrossRef]

26. Zhang, Y.; Li, J.; Lou, J.; Zhou, Y.; Bo, L.; Zhu, J.; Zhu, K.; Wan, X.; Cai, Z.; Deng, X. Upregulation of programmed death-1 on $\mathrm{T}$ cells and programmed death ligand-1 on monocytes in septic shock patients. Crit. Care 2011, 15, R70. [CrossRef]

27. De Pablo, R.; Monserrat, J.; Prieto, A.; Alvarez-Mon, M. Role of circulating lymphocytes in patients with sepsis. BioMed Res. Int. 2014, 2014, 671087. [CrossRef]

28. Hotchkiss, R.S.; Monneret, G.; Payen, D. Sepsis-induced immunosuppression: From cellular dysfunctions to immunotherapy. Nat. Rev. Immunol. 2013, 13, 862-874. [CrossRef] 
29. Hynninen, M.; Pettila, V.; Takkunen, O.; Orko, R.; Jansson, S.E.; Kuusela, P.; Renkonen, R.; Valtonen, M. Predictive value of monocyte histocompatibility leukocyte antigen-DR expression and plasma interleukin-4 and -10 levels in critically ill patients with sepsis. Shock 2003, 20,1-4. [CrossRef]

30. Shankar-Hari, M.; Datta, D.; Wilson, J.; Assi, V.; Stephen, J.; Weir, C.J.; Rennie, J.; Antonelli, J.; Bateman, A.; Felton, J.M.; et al. Early PREdiction of sepsis using leukocyte surface biomarkers: The ExPRES-sepsis cohort study. Intensive Care Med. 2018, 44, 1836-1848. [CrossRef]

31. Pena, O.M.; Hancock, D.G.; Lyle, N.H.; Linder, A.; Russell, J.A.; Xia, J.; Fjell, C.D.; Boyd, J.H.; Hancock, R.E. An Endotoxin Tolerance Signature Predicts Sepsis and Organ Dysfunction at Initial Clinical Presentation. EBioMedicine 2014, 1, 64-71. [CrossRef] [PubMed]

32. Drifte, G.; Dunn-Siegrist, I.; Tissieres, P.; Pugin, J. Innate immune functions of immature neutrophils in patients with sepsis and severe systemic inflammatory response syndrome. Crit. Care Med. 2013, 41, 820-832. [CrossRef]

33. Daix, T.; Guerin, E.; Tavernier, E.; Mercier, E.; Gissot, V.; Herault, O.; Mira, J.P.; Dumas, F.; Chapuis, N.; Guitton, C.; et al. Multicentric Standardized Flow Cytometry Routine Assessment of Patients With Sepsis to Predict Clinical Worsening. Chest 2018, 154, 617-627. [CrossRef] [PubMed]

34. Cox, L.E.; Walstein, K.; Vollger, L.; Reuner, F.; Bick, A.; Dotsch, A.; Engler, A.; Peters, J.; von Kockritz-Blickwede, M.; Schafer, S.T. Neutrophil extracellular trap formation and nuclease activity in septic patients. BMC Anesthesiol. 2020, 20, 15. [CrossRef] [PubMed]

35. Simmons, J.; Pittet, J.F. The coagulopathy of acute sepsis. Curr. Opin. Anaesthesiol. 2015, 28, $227-236$. [CrossRef] [PubMed]

36. Kaplan, M.J.; Radic, M. Neutrophil extracellular traps: Double-edged swords of innate immunity. J. Immunol. 2012, 189, 2689-2695. [CrossRef]

37. Lu, T.; Kobayashi, S.D.; Quinn, M.T.; Deleo, F.R. A NET Outcome. Front. Immunol. 2012, 3, 365. [CrossRef]

38. Ortmann, W.; Kolaczkowska, E. Age is the work of art? Impact of neutrophil and organism age on neutrophil extracellular trap formation. Cell Tissue Res. 2018, 371, 473-488. [CrossRef]

39. Camicia, G.; Pozner, R.; de Larranaga, G. Neutrophil extracellular traps in sepsis. Shock 2014, 42, $286-294$. [CrossRef]

40. Cuenca, A.G.; Delano, M.J.; Kelly-Scumpia, K.M.; Moreno, C.; Scumpia, P.O.; Laface, D.M.; Heyworth, P.G.; Efron, P.A.; Moldawer, L.L. A paradoxical role for myeloid-derived suppressor cells in sepsis and trauma. Mol. Med. 2011, 17, 281-292. [CrossRef]

41. Veglia, F.; Perego, M.; Gabrilovich, D. Myeloid-derived suppressor cells coming of age. Nat. Immunol. 2018, 19, 108-119. [CrossRef] [PubMed]

42. Durandy, A.; Kaveri, S.V.; Kuijpers, T.W.; Basta, M.; Miescher, S.; Ravetch, J.V.; Rieben, R. Intravenous immunoglobulins-understanding properties and mechanisms. Clin. Exp. Immunol. 2009, 158 (Suppl. 1), 2-13. [CrossRef] [PubMed]

43. Chousterman, B.G.; Swirski, F.K. Innate response activator B cells: Origins and functions. Int. Immunol. 2015, 27, 537-541. [CrossRef] [PubMed]

44. Weber, G.F.; Chousterman, B.G.; He, S.; Fenn, A.M.; Nairz, M.; Anzai, A.; Brenner, T.; Uhle, F.; Iwamoto, Y.; Robbins, C.S.; et al. Interleukin-3 amplifies acute inflammation and is a potential therapeutic target in sepsis. Science 2015, 347, 1260-1265. [CrossRef] [PubMed]

45. Park, S.H.; Park, B.G.; Park, C.J.; Kim, S.; Kim, D.H.; Jang, S.; Hong, S.K.; Chi, H.S. An extended leukocyte differential count (16 types of circulating leukocytes) using the cytodiff flow cytometric system can provide informations for the discrimination of sepsis severity and prediction of outcome in sepsis patients. Cytom. Part B Clin. Cytom. 2013, 86, 244-256. [CrossRef] [PubMed]

46. Monserrat, J.; de Pablo, R.; Diaz-Martin, D.; Rodriguez-Zapata, M.; de la Hera, A.; Prieto, A.; Alvarez-Mon, M. Early alterations of B cells in patients with septic shock. Crit. Care 2013, 17, R105. [CrossRef] [PubMed]

47. Dong, X.; Liu, Q.; Zheng, Q.; Liu, X.; Wang, Y.; Xie, Z.; Liu, T.; Yang, F.; Gao, W.; Bai, X.; et al. Alterations of B Cells in Immunosuppressive Phase of Septic Shock Patients. Crit. Care Med. 2020, 48, 815-821. [CrossRef]

48. Krautz, C.; Maier, S.L.; Brunner, M.; Langheinrich, M.; Giamarellos-Bourboulis, E.J.; Gogos, C.; Armaganidis, A.; Kunath, F.; Grutzmann, R.; Weber, G.F. Reduced circulating B cells and plasma IgM levels are associated with decreased survival in sepsis-A meta-analysis. J. Crit. Care 2018, 45, 71-75. [CrossRef] 
49. Andaluz-Ojeda, D.; Iglesias, V.; Bobillo, F.; Nocito, M.; Loma, A.M.; Nieto, C.; Ramos, E.; Gandia, F.; Rico, L.; Bermejo-Martin, J.F. Early levels in blood of immunoglobulin $\mathrm{M}$ and natural killer cells predict outcome in nonseptic critically ill patients. J. Crit. Care 2013, 28, 1110-e7-1110-e10. [CrossRef]

50. Shankar-Hari, M.; Spencer, J.; Sewell, W.A.; Rowan, K.M.; Singer, M. Bench-to-bedside review: Immunoglobulin therapy for sepsis-biological plausibility from a critical care perspective. Crit. Care 2012, 16, 206. [CrossRef]

51. Shankar-Hari, M.; Singer, M.; Spencer, J. Can Concurrent Abnormalities in Free Light Chains and Immunoglobulin Concentrations Identify a Target Population for Immunoglobulin Trials in Sepsis? Crit. Care Med. 2017, 45, 1829-1836. [CrossRef]

52. Sjoberg, A.P.; Trouw, L.A.; Blom, A.M. Complement activation and inhibition: A delicate balance. Trends Immunol. 2009, 30, 83-90. [CrossRef] [PubMed]

53. Seely, A.J.; Naud, J.F.; Campisi, G.; Giannias, B.; Liu, S.; DiCarlo, A.; Ferri, L.E.; Pascual, J.L.; Tchervenkov, J.; Christou, N.V. Alteration of chemoattractant receptor expression regulates human neutrophil chemotaxis in vivo. Ann. Surg. 2002, 235, 550-559. [CrossRef] [PubMed]

54. Seely, A.J.; Pascual, J.L.; Christou, N.V. Science review: Cell membrane expression (connectivity) regulates neutrophil delivery, function and clearance. Crit. Care 2003, 7, 291-307. [CrossRef] [PubMed]

55. Takei, S.; Arora, Y.K.; Walker, S.M. Intravenous immunoglobulin contains specific antibodies inhibitory to activation of T cells by staphylococcal toxin superantigens [see comment]. J. Clin. Investig. 1993, 91, 602-607. [CrossRef]

56. Darville, T.; Milligan, L.B.; Laffoon, K.K. Intravenous immunoglobulin inhibits staphylococcal toxin-induced human mononuclear phagocyte tumor necrosis factor alpha production. Infect. Immun. 1997, 65, 366-372. [CrossRef]

57. Bueno, C.; Criado, G.; McCormick, J.K.; Madrenas, J. T cell signalling induced by bacterial superantigens. Chem. Immunol. Allergy 2007, 93, 161-180. [CrossRef]

58. Cinel, I.; Opal, S.M. Molecular biology of inflammation and sepsis: A primer. Crit. Care Med. 2009, 37, 291-304. [CrossRef]

59. Aukrust, P.; Muller, F.; Svenson, M.; Nordoy, I.; Bendtzen, K.; Froland, S.S. Administration of intravenous immunoglobulin (IVIG) in vivo-down-regulatory effects on the IL-1 system. Clin. Exp. Immunol. 1999, 115, 136-143. [CrossRef]

60. Sewell, W.A.; Jolles, S. Immunomodulatory action of intravenous immunoglobulin. Immunology 2002, 107, 387-393. [CrossRef]

61. Bendtzen, K.; Hansen, M.B.; Ross, C.; Svenson, M. Detection of autoantibodies to cytokines. Mol. Biotechnol. 2000, 14, 251-261. [CrossRef]

62. Menezes, M.C.; Benard, G.; Sato, M.N.; Hong, M.A.; Duarte, A.J. In vitro inhibitory activity of tumor necrosis factor alpha and interleukin-2 of human immunoglobulin preparations. Int. Arch. Allergy Immunol. 1997, 114, 323-328. [CrossRef]

63. Ross, C.; Svenson, M.; Nielsen, H.; Lundsgaard, C.; Hansen, M.B.; Bendtzen, K. Increased in vivo antibody activity against interferon alpha, interleukin-1alpha, and interleukin-6 after high-dose Ig therapy. Blood 1997, 90, 2376-2380. [CrossRef] [PubMed]

64. Werdan, K.; Pilz, G.; Bujdoso, O.; Fraunberger, P.; Neeser, G.; Schmieder, R.E.; Viell, B.; Marget, W.; Seewald, M.; Walger, P.; et al. Score-based immunoglobulin G therapy of patients with sepsis: The SBITS study. Crit. Care Med. 2007, 35, 2693-2701. [PubMed]

65. Werdan, K.; Pilz, G.; Muller-Werdan, U.; Maas Enriquez, M.; Schmitt, D.V.; Mohr, F.W.; Neeser, G.; Schondube, F.; Schafers, H.J.; Haverich, A.; et al. Immunoglobulin G treatment of postcardiac surgery patients with score-identified severe systemic inflammatory response syndrome-The ESSICS study. Crit. Care Med. 2008, 36, 716-723. [CrossRef] [PubMed]

66. Group, I.C.; Brocklehurst, P.; Farrell, B.; King, A.; Juszczak, E.; Darlow, B.; Haque, K.; Salt, A.; Stenson, B.; Tarnow-Mordi, W. Treatment of neonatal sepsis with intravenous immune globulin. N. Engl. J. Med. 2011, 365, 1201-1211. [CrossRef]

67. Cui, J.; Wei, X.; Lv, H.; Li, Y.; Li, P.; Chen, Z.; Liu, G. The clinical efficacy of intravenous IgM-enriched immunoglobulin (pentaglobin) in sepsis or septic shock: A meta-analysis with trial sequential analysis. Ann. Intensive Care 2019, 9, 27. [CrossRef] 
68. Kreymann, K.G.; de Heer, G.; Nierhaus, A.; Kluge, S. Use of polyclonal immunoglobulins as adjunctive therapy for sepsis or septic shock. Crit. Care Med. 2007, 35, 2677-2685.

69. Alejandria, M.M.; Lansang, M.A.; Dans, L.F.; Mantaring, J.B., III. Intravenous immunoglobulin for treating sepsis, severe sepsis and septic shock. Cochrane Database Syst. Rev. 2013. [CrossRef]

70. Giamarellos-Bourboulis, E.J.; Tziolos, N.; Routsi, C.; Katsenos, C.; Tsangaris, I.; Pneumatikos, I.; Vlachogiannis, G.; Theodorou, V.; Prekates, A.; Antypa, E.; et al. Improving outcomes of severe infections by multidrug-resistant pathogens with polyclonal IgM-enriched immunoglobulins. Clin. Microbiol. Infect. 2016, 22, 499-506. [CrossRef]

71. Cavazzuti, I.; Serafini, G.; Busani, S.; Rinaldi, L.; Biagioni, E.; Buoncristiano, M.; Girardis, M. Early therapy with IgM-enriched polyclonal immunoglobulin in patients with septic shock. Intensive Care Med. 2014, 40, 1888-1896. [CrossRef] [PubMed]

72. Welte, T.; Dellinger, R.P.; Ebelt, H.; Ferrer, M.; Opal, S.M.; Singer, M.; Vincent, J.L.; Werdan, K.; Martin-Loeches, I.; Almirall, J.; et al. Efficacy and safety of trimodulin, a novel polyclonal antibody preparation, in patients with severe community-acquired pneumonia: A randomized, placebo-controlled, double-blind, multicenter, phase II trial (CIGMA study). Intensive Care Med. 2018, 44, 438-448. [CrossRef] [PubMed]

73. Domizi, R.; Adrario, E.; Damiani, E.; Scorcella, C.; Carsetti, A.; Giaccaglia, P.; Casarotta, E.; Gabbanelli, V.; Pantanetti, S.; Lamura, E.; et al. IgM-enriched immunoglobulins (Pentaglobin) may improve the microcirculation in sepsis: A pilot randomized trial. Ann. Intensive Care 2019, 9, 135. [CrossRef]

74. Hoffman, J.N.; Fertmann, J.M.; Vollmar, B.; Laschke, M.W.; Jauch, K.W.; Menger, M.D. Immunoglobulin M-enriched human intravenous immunoglobulins reduce leukocyte-endothelial cell interactions and attenuate microvascular perfusion failure in normotensive endotoxemia. Shock 2008, 29, 133-139. [CrossRef]

75. Esen, F.; Orhun, G.; Ozcan, P.E.; Senturk, E.; Kucukerden, M.; Giris, M.; Akcan, U.; Yilmaz, C.U.; Orhan, N.; Arican, N.; et al. Neuroprotective effects of intravenous immunoglobulin are mediated through inhibition of complement activation and apoptosis in a rat model of sepsis. Intensive Care Med. Exp. 2017, 5, 1. [CrossRef] [PubMed]

76. Esen, F.; Senturk, E.; Ozcan, P.E.; Ahishali, B.; Arican, N.; Orhan, N.; Ekizoglu, O.; Kucuk, M.; Kaya, M. Intravenous immunoglobulins prevent the breakdown of the blood-brain barrier in experimentally induced sepsis. Crit. Care Med. 2012, 40, 1214-1220. [CrossRef]

77. Behre, G.; Schedel, I.; Nentwig, B.; Wormann, B.; Essink, M.; Hiddemann, W. Endotoxin concentration in neutropenic patients with suspected gram-negative sepsis: Correlation with clinical outcome and determination of anti-endotoxin core antibodies during therapy with polyclonal immunoglobulin M-enriched immunoglobulins. Antimicrob. Agents Chemother. 1992, 36, 2139-2146. [CrossRef]

78. El-Nawawy, A.; El-Kinany, H.; Hamdy El-Sayed, M.; Boshra, N. Intravenous polyclonal immunoglobulin administration to sepsis syndrome patients: A prospective study in a pediatric intensive care unit. J. Trop. Pediatr. 2005, 51, 271-278. [CrossRef]

79. Capasso, L.; Borrelli, A.C.; Parrella, C.; Lama, S.; Ferrara, T.; Coppola, C.; Catania, M.R.; Iula, V.D.; Raimondi, F. Are IgM-enriched immunoglobulins an effective adjuvant in septic VLBW infants? Ital. J. Pediatr. 2013, $39,63$. [CrossRef]

80. Wand, S.; Klages, M.; Kirbach, C.; Warszawska, J.; Meybohm, P.; Zacharowski, K.; Koch, A. IgM-Enriched Immunoglobulin Attenuates Systemic Endotoxin Activity in Early Severe Sepsis: A Before-After Cohort Study. PLoS ONE 2016, 11, e0160907. [CrossRef]

81. Stehr, S.N.; Knels, L.; Weissflog, C.; Schober, J.; Haufe, D.; Lupp, A.; Koch, T.; Heller, A.R. Effects of IGM-enriched solution on polymorphonuclear neutrophil function, bacterial clearance, and lung histology in endotoxemia. Shock 2008, 29, 167-172. [CrossRef] [PubMed]

82. Rieben, R.; Roos, A.; Muizert, Y.; Tinguely, C.; Gerritsen, A.F.; Daha, M.R. Immunoglobulin M-enriched human intravenous immunoglobulin prevents complement activation in vitro and in vivo in a rat model of acute inflammation. Blood 1999, 93, 942-951. [CrossRef]

83. Walpen, A.J.; Laumonier, T.; Aebi, C.; Mohacsi, P.J.; Rieben, R. Immunoglobulin M-enriched intravenous immunoglobulin inhibits classical pathway complement activation, but not bactericidal activity of human serum. Xenotransplantation 2004, 11, 141-148. [CrossRef] [PubMed] 
84. Nachbaur, D.; Herold, M.; Gachter, A.; Niederwieser, D. Modulation of alloimmune response in vitro by an IgM-enriched immunoglobulin preparation (Pentaglobin). Immunology 1998, 94, 279-283. [CrossRef] [PubMed]

85. Abbas, A.K.; Trotta, E.; Simeonov, D.R.; Marson, A.; Bluestone, J.A. Revisiting IL-2: Biology and therapeutic prospects. Sci. Immunol. 2018, 3. [CrossRef]

86. Ghelani, A.; Bates, D.; Conner, K.; Wu, M.Z.; Lu, J.; Hu, Y.L.; Li, C.M.; Chaudhry, A.; Sohn, S.J. Defining the Threshold IL-2 Signal Required for Induction of Selective Treg Cell Responses Using Engineered IL-2 Muteins. Front. Immunol. 2020, 11, 1106. [CrossRef]

87. Paul, W.E.; Zhu, J. How are T(H)2-type immune responses initiated and amplified? Nat. Rev. Immunol. 2010, 10, 225-235. [CrossRef]

88. Dantal, J. Intravenous immunoglobulins: In-depth review of excipients and acute kidney injury risk. Am. J. Nephrol. 2013, 38, 275-284. [CrossRef]

89. Katz, U.; Achiron, A.; Sherer, Y.; Shoenfeld, Y. Safety of intravenous immunoglobulin (IVIG) therapy. Autoimmun. Rev. 2007, 6, 257-259. [CrossRef]

90. Rhodes, A.; Evans, L.E.; Alhazzani, W.; Levy, M.M.; Antonelli, M.; Ferrer, R.; Kumar, A.; Sevransky, J.E.; Sprung, C.L.; Nunnally, M.E.; et al. Surviving Sepsis Campaign: International Guidelines for Management of Sepsis and Septic Shock: 2016. Intensive Care Med. 2017, 43, 304-377. [CrossRef]

91. Azevedo, L.C.; Park, M.; Schettino, G.P. Novel potential therapies for septic shock. Shock 2008, 30 (Suppl. 1), 60-66. [CrossRef] [PubMed]

92. Vaschetto, R.; Clemente, N.; Pagni, A.; Esposito, T.; Longhini, F.; Mercalli, F.; Boggio, E.; Boldorini, R.; Chiocchetti, A.; Dianzani, U.; et al. A double blind randomized experimental study on the use of IgM-enriched polyclonal immunoglobulins in an animal model of pneumonia developing shock. Immunobiology 2017, 222, 1074-1080. [CrossRef] [PubMed]

93. Barratt-Due, A.; Sokolov, A.; Gustavsen, A.; Hellerud, B.C.; Egge, K.; Pischke, S.E.; Lindstad, J.K.; Pharo, A.; Castellheim, A.; Thorgersen, E.B.; et al. Polyvalent immunoglobulin significantly attenuated the formation of IL-1beta in Escherichia coli-induced sepsis in pigs. Immunobiology 2013, 218, 683-689. [CrossRef] [PubMed]

94. Kakoullis, L.; Pantzaris, N.D.; Platanaki, C.; Lagadinou, M.; Papachristodoulou, E.; Velissaris, D. The use of IgM-enriched immunoglobulin in adult patients with sepsis. J. Crit. Care 2018, 47, 30-35. [CrossRef] [PubMed]

95. Marshall, J.C. Why have clinical trials in sepsis failed? Trends Mol. Med. 2014, 20, 195-203. [CrossRef]

96. Cohen, J.; Vincent, J.L.; Adhikari, N.K.; Machado, F.R.; Angus, D.C.; Calandra, T.; Jaton, K.; Giulieri, S.; Delaloye, J.; Opal, S.; et al. Sepsis: A roadmap for future research. Lancet Infect. Dis. 2015, 15, 581-614. [CrossRef]

97. Delano, M.J.; Ward, P.A. Sepsis-induced immune dysfunction: Can immune therapies reduce mortality? J. Clin. Investig. 2016, 126, 23-31. [CrossRef]

98. Santacruz, C.A.; Pereira, A.J.; Celis, E.; Vincent, J.L. Which Multicenter Randomized Controlled Trials in Critical Care Medicine Have Shown Reduced Mortality? A Systematic Review. Crit. Care Med. 2019, 47, 1680-1691. [CrossRef]

99. Geier, C.; Schroder, J.; Tamm, A.; Dietz, S.; Nuding, S.; Holder, K.; Khandanpour, O.; Werdan, K.; Ebelt, H. Influence of the serum levels of immunoglobulins on clinical outcomes in medical intensive-care patients. Med. Klin. Intensivmed. Notfallmed. 2017, 112, 30-37. [CrossRef]

100. Soares, M.O.; Welton, N.J.; Harrison, D.A.; Peura, P.; Shankar-Hari, M.; Harvey, S.E.; Madan, J.J.; Ades, A.E.; Palmer, S.J.; Rowan, K.M. An evaluation of the feasibility, cost and value of information of a multicentre randomised controlled trial of intravenous immunoglobulin for sepsis (severe sepsis and septic shock): Incorporating a systematic review, meta-analysis and value of information analysis. Health Technol. Assess. 2012, 16, 1-186. [CrossRef]

101. Turgeon, A.F.; Hutton, B.; Fergusson, D.A.; McIntyre, L.; Tinmouth, A.A.; Cameron, D.W.; Hebert, P.C. Meta-analysis: Intravenous immunoglobulin in critically ill adult patients with sepsis. Ann. Intern. Med. 2007, 146, 193-203. [CrossRef] [PubMed]

102. Antcliffe, D.B.; Gordon, A.C. Why Understanding Sepsis Endotypes Is Important for Steroid Trials in Septic Shock. Crit. Care Med. 2019, 47, 1782-1784. [CrossRef] [PubMed]

103. Pinheiro da Silva, F.; Cesar Machado, M.C. Personalized Medicine for Sepsis. Am. J. Med. Sci. 2015, 350, 409-413. [CrossRef] [PubMed] 
104. Christaki, E.; Giamarellos-Bourboulis, E.J. The beginning of personalized medicine in sepsis: Small steps to a bright future. Clin. Genet. 2014, 86, 56-61. [CrossRef] [PubMed]

105. Neilson, A.R.; Burchardi, H.; Schneider, H. Cost-effectiveness of immunoglobulin M-enriched immunoglobulin (Pentaglobin) in the treatment of severe sepsis and septic shock. J. Crit. Care 2005, 20, 239-249. [CrossRef]

106. Grossmann, S.; Schroll, S.; Pfeifer, M. [Procalcitonin in the intensive care unit: Differential diagnostic and differential therapeutic possibilities]. Med. Klin. Intensivmed. Notfallmed. 2020. [CrossRef]

107. Tseng, J.; Nugent, K. Utility of the shock index in patients with sepsis. Am. J. Med. Sci. 2015, 349, 531-535. [CrossRef]

108. Berger, T.; Green, J.; Horeczko, T.; Hagar, Y.; Garg, N.; Suarez, A.; Panacek, E.; Shapiro, N. Shock index and early recognition of sepsis in the emergency department: Pilot study. West. J. Emerg. Med. 2013, 14, 168-174. [CrossRef]

109. Shankar-Hari, M.; Culshaw, N.; Post, B.; Tamayo, E.; Andaluz-Ojeda, D.; Bermejo-Martin, J.F.; Dietz, S.; Werdan, K.; Beale, R.; Spencer, J.; et al. Endogenous IgG hypogammaglobulinaemia in critically ill adults with sepsis: Systematic review and meta-analysis. Intensive Care Med. 2015, 41, 1393-1401. [CrossRef]

110. Bermejo-Martin, J.F.; Rodriguez-Fernandez, A.; Herran-Monge, R.; Andaluz-Ojeda, D.; Muriel-Bombin, A.; Merino, P.; Garcia-Garcia, M.M.; Citores, R.; Gandia, F.; Almansa, R.; et al. Immunoglobulins IgG1, IgM and IgA: A synergistic team influencing survival in sepsis. J. Intern. Med. 2014, 276, 404-412. [CrossRef]

111. Berlot, G.; Vassallo, M.C.; Busetto, N.; Bianchi, M.; Zornada, F.; Rosato, I.; Tartamella, F.; Prisco, L.; Bigotto, F.; Bigolin, T.; et al. Relationship between the timing of administration of IgM and IgA enriched immunoglobulins in patients with severe sepsis and septic shock and the outcome: A retrospective analysis. J. Crit. Care 2012, 27, 167-171. [CrossRef] [PubMed]

112. Peters van Ton, A.M.; Kox, M.; Abdo, W.F.; Pickkers, P. Precision Immunotherapy for Sepsis. Front. Immunol. 2018, 9, 1926. [CrossRef]

113. Winters, B.D.; Eberlein, M.; Leung, J.; Needham, D.M.; Pronovost, P.J.; Sevransky, J.E. Long-term mortality and quality of life in sepsis: A systematic review. Crit. Care Med. 2010, 38, 1276-1283. [CrossRef] [PubMed]

114. Wang, T.; Derhovanessian, A.; De Cruz, S.; Belperio, J.A.; Deng, J.C.; Hoo, G.S. Subsequent infections in survivors of sepsis: Epidemiology and outcomes. J. Intensive Care Med. 2014, 29, 87-95. [CrossRef] [PubMed]

115. Venet, F.; Monneret, G. Advances in the understanding and treatment of sepsis-induced immunosuppression. Nat. Rev. Nephrol. 2018, 14, 121-137. [CrossRef] [PubMed]

116. Mira, J.C.; Gentile, L.F.; Mathias, B.J.; Efron, P.A.; Brakenridge, S.C.; Mohr, A.M.; Moore, F.A.; Moldawer, L.L. Sepsis Pathophysiology, Chronic Critical Illness, and Persistent Inflammation-Immunosuppression and Catabolism Syndrome. Crit. Care Med. 2017, 45, 253-262. [CrossRef]

117. Efron, P.A.; Mohr, A.M.; Bihorac, A.; Horiguchi, H.; Hollen, M.K.; Segal, M.S.; Baker, H.V.; Leeuwenburgh, C.; Moldawer, L.L.; Moore, F.A.; et al. Persistent inflammation, immunosuppression, and catabolism and the development of chronic critical illness after surgery. Surgery 2018, 164, 178-184. [CrossRef]

118. Schefold, J.C. Measurement of monocytic HLA-DR (mHLA-DR) expression in patients with severe sepsis and septic shock: Assessment of immune organ failure. Intensive Care Med. 2010, 36, 1810-1812. [CrossRef]

119. Drewry, A.M.; Ablordeppey, E.A.; Murray, E.T.; Beiter, E.R.; Walton, A.H.; Hall, M.W.; Hotchkiss, R.S. Comparison of monocyte human leukocyte antigen-DR expression and stimulated tumor necrosis factor alpha production as outcome predictors in severe sepsis: A prospective observational study. Crit. Care 2016, 20, 334. [CrossRef]

120. Pfortmueller, C.A.; Meisel, C.; Fux, M.; Schefold, J.C. Assessment of immune organ dysfunction in critical illness: Utility of innate immune response markers. Intensive Care Med. Exp. 2017, 5, 49. [CrossRef]

121. Berlot, G.; Vassallo, M.C.; Busetto, N.; Nieto Yabar, M.; Istrati, T.; Baronio, S.; Quarantotto, G.; Bixio, M.; Barbati, G.; Dattola, R.; et al. Effects of the timing of administration of IgM- and IgA-enriched intravenous polyclonal immunoglobulins on the outcome of septic shock patients. Ann. Intensive Care 2018, 8, 122. [CrossRef] [PubMed]

122. Molnar, Z.; Giamarellos-Bourboulis, E.J.; Kumar, A.; Nierhaus, A. Sepsis: Diagnostic and Therapeutic Challenges. BioMed Res. Int. 2016, 2016, 5786182. [CrossRef]

123. Zumla, A.; Hui, D.S.; Azhar, E.I.; Memish, Z.A.; Maeurer, M. Reducing mortality from 2019-nCoV: Host-directed therapies should be an option. Lancet 2020, 395, e35-e36. [CrossRef] 
124. Huang, C.; Wang, Y.; Li, X.; Ren, L.; Zhao, J.; Hu, Y.; Zhang, L.; Fan, G.; Xu, J.; Gu, X.; et al. Clinical features of patients infected with 2019 novel coronavirus in Wuhan, China. Lancet 2020, 395, 497-506. [CrossRef]

125. Zhang, H.; Zhou, P.; Wei, Y.; Yue, H.; Wang, Y.; Hu, M.; Zhang, S.; Cao, T.; Yang, C.; Li, M.; et al. Histopathologic Changes and SARS-CoV-2 Immunostaining in the Lung of a Patient With COVID-19. Ann. Intern. Med. 2020, 172, 629-632. [CrossRef] [PubMed]

126. Yang, Y.; Shen, C.; Li, J.; Yuan, J.; Wei, J.; Huang, F.; Wang, F.; Li, G.; Li, Y.; Xing, L.; et al. Plasma IP-10 and MCP-3 levels are highly associated with disease severity and predict the progression of COVID-19. J Allergy Clin. Immunol. 2020, 146, 119-127.e114. [CrossRef]

127. Jiang, Y.; Xu, J.; Zhou, C.; Wu, Z.; Zhong, S.; Liu, J.; Luo, W.; Chen, T.; Qin, Q.; Deng, P. Characterization of cytokine/chemokine profiles of severe acute respiratory syndrome. Am. J. Respir. Crit. Care Med. 2005, 171, 850-857. [CrossRef]

128. Vaninov, N. In the eye of the COVID-19 cytokine storm. Nat. Rev. Immunol. 2020, 20, 277. [CrossRef]

129. Wichmann, D.; Sperhake, J.P.; Lutgehetmann, M.; Steurer, S.; Edler, C.; Heinemann, A.; Heinrich, F.; Mushumba, H.; Kniep, I.; Schroder, A.S.; et al. Autopsy Findings and Venous Thromboembolism in Patients With COVID-19. Ann. Intern. Med. 2020. [CrossRef]

130. Giamarellos-Bourboulis, E.J.; Netea, M.G.; Rovina, N.; Akinosoglou, K.; Antoniadou, A.; Antonakos, N.; Damoraki, G.; Gkavogianni, T.; Adami, M.E.; Katsaounou, P.; et al. Complex Immune Dysregulation in COVID-19 Patients with Severe Respiratory Failure. Cell Host Microbe 2020, 27, 992-1000.e3. [CrossRef]

131. Liu, Y.; Yan, L.M.; Wan, L.; Xiang, T.X.; Le, A.; Liu, J.M.; Peiris, M.; Poon, L.L.M.; Zhang, W. Viral dynamics in mild and severe cases of COVID-19. Lancet. Infect. Dis. 2020, 20, 656-657. [CrossRef]

132. Rello, J.; Valenzuela-Sanchez, F.; Ruiz-Rodriguez, M.; Moyano, S. Sepsis: A Review of Advances in Management. Adv. Ther. 2017, 34, 2393-2411. [CrossRef] [PubMed]

133. Freeman, B.D.; Natanson, C. Anti-inflammatory therapies in sepsis and septic shock. Expert Opin. Investig. Drugs 2000, 9, 1651-1663. [CrossRef] [PubMed]

(C) 2020 by the authors. Licensee MDPI, Basel, Switzerland. This article is an open access article distributed under the terms and conditions of the Creative Commons Attribution (CC BY) license (http://creativecommons.org/licenses/by/4.0/). 